\title{
AGGREGATE DISTRIBUTION, STABILITY AND RELEASE OF WATER DISPERSIBLE CLAY FOR TWO SUBTROPICAL OXISOLS
}

\author{
Antonio Carlos de Azevedo ${ }^{1 *}$; Darrel Gene Schulze ${ }^{2}$ \\ ${ }^{1}$ UFSM - Depto. de Solos, Prédio 42 - 97105-900 - Santa Maria, RS - Brasil. \\ ${ }^{2}$ PURDUE UNIVERSITY- Agronomy Dept., Lilly Hall of Life Sciences, 915 W. State Street, West Lafayette, IN \\ 47907-2054, USA. \\ *Corresponding author <aazevedo@ccr.ufsm.br>
}

\begin{abstract}
The behavior of a soil regarding the dispersion and aggregation of its particles is very important for the development of environmental and agricultural soil functions. This study was conducted to determine how aggregate distribution and stability are impacted by land uses and how the release of Water Dispersible Clay (WDC) relates to disaggregation in Oxisols from subtropical Brazil. Samples from two Oxisols, collected at three depths from sites under no-tillage (NT), conventional tillage (CT) and native vegetation (NV) land uses were shaken in $250 \mathrm{~mL}$ plastic bottles for intervals up to 27 hours. The mass of aggregates was measured in five size classes ranging from 53 to $2000 \mathrm{Pm}$. Most aggregates larger than $500 \mathrm{Pm}$ disappeared during the first 7.5 hours of shaking, concurrent with an increase in WDC release and without change in soil suspension $\mathrm{pH}$ and electrical conductivity, without increase in smaller aggregates. Therefore, there is no aggregate hierarchy in these soils and the release of WDC was caused by breaking aggregates within the 500 to $2000 \mathrm{Pm}$ range. Land uses affect mass of aggregates in each size class, but the aggregate stability depends on its size, not land use.

Key words: land use, disaggregation, soil tillage, soil management
\end{abstract}

\section{DISTRIBUIÇÃO DE AGREGADOS, ESTABILIDADE E LIBERAÇÃO DE ARGILA DISPERSA EM ÁGUA PARA DOIS LATOSSOLOS SUBTROPICAIS}

\begin{abstract}
RESUMO: O comportamento do solo em relação ao seu estado de agregação e dispersão é de alta relevância agrícola e ambiental. Este estudo foi conduzido para determinar como a distribuição e estabilidade de agregados são afetados por diferentes usos e como a liberação de argila dispersa em água (WDC) se comporta em relação à desagregação em Latossolos subtropicais brasileiros. Amostras de dois Latossolos coletadas em três profundidades em locais sob plantio direto (NT), plantio convencional (CT) e vegetação nativa (NV) foram agitados em garrafas plásticas de $250 \mathrm{~mL}$ por até 27 horas. A massa de agregados foi medida em cinco classes de tamanho desde 53 até $2000 \mathrm{Pm}$. A maioria dos agregados maiores que 500 Pm desapareceu durante as primeiras 7,5 horas de agitação, paralelamente à um aumento na liberação de WDC sem variação nos valores de $\mathrm{pH}$ e condutividade elétrica da suspensão, e sem aumento na massa de agregados menores. Portanto, não há hierarquia de agregados nestes solos e a liberação de WDC foi causada pela quebra de agregados com tamanho no intervalo entre 500 e $2000 \mathrm{Pm}$. O tipo de uso afetou a massa de agregados em cada classe de tamanho mas a estabilidade de agregados é dependente do seu tamanho, não do tipo de uso.

Palavras-chave: uso da terra, desagregação, preparo do solo, manejo do solo
\end{abstract}

\section{INTRODUCTION}

Because soil aggregates are dynamic and respond rapidly to environmental changes, interest on them as soil quality indicators is growing (Caravaca et al., 2004; Boix-Fayos et al., 2001). In addition, the capability of soil particles to protect organic matter from oxidation allows to approach soils as a carbon sink to the atmosphere (Torn et al., 1997). Land use change caused by tree harvesting (Yanai et al., 2003) and/or change from forest to agriculture has an extensive impact on aggregation (Carpenedo \& Mielniczuk, 1990; Perin et al., 2003) and carbon dynamics in tropical, acid soils (Leite et al., 2004; Zinn et al., 2005). The lack of aggregate hierarchy (Oades \& Waters, 1991) and great amount of iron and aluminum oxides 
make stability and size of aggregates from weathered Oxisols require specific studies. In Brazil, such soils tend to have very stable aggregates less than $2 \mathrm{~mm}$ in diameter. As a result, clayey Oxisols behave like medium-textured soils allowing agricultural activities such as tillage or harvest to occur soon after raining (Buol \& Eswaran, 2000). The potential to release water dispersible clay (WDC) due to disaggregation is not well known for these soils (Azevedo \& Bonumá, 2004) and such knowledge may help to better manage these soils during changes in land use, and is important for evaluating the environmental mobility of herbicides, pesticides, and other xenobiotic compounds used in agriculture (Seta \& Karathanasis, 1996; Bertsch \& Seaman, 1999).

The objective of this study was to evaluate the long-term impact of management practices on the distribution and stability of aggregates of less than $2 \mathrm{~mm}$ diameter and the release of WDC during disaggregation for two Oxisols from Southern Brazil.

\section{MATERIAL AND METHODS}

The two chosen sites were located on the Sul Riograndense Plateau, a geomorphic region developed on the lava flows of the Serra Geral formation (Figure 1). The soil at the Santo Ângelo site was a Typic Haplorthox developed from basaltic rocks, occupies $7.26 \%$ of the Rio Grande do Sul State and occurs at

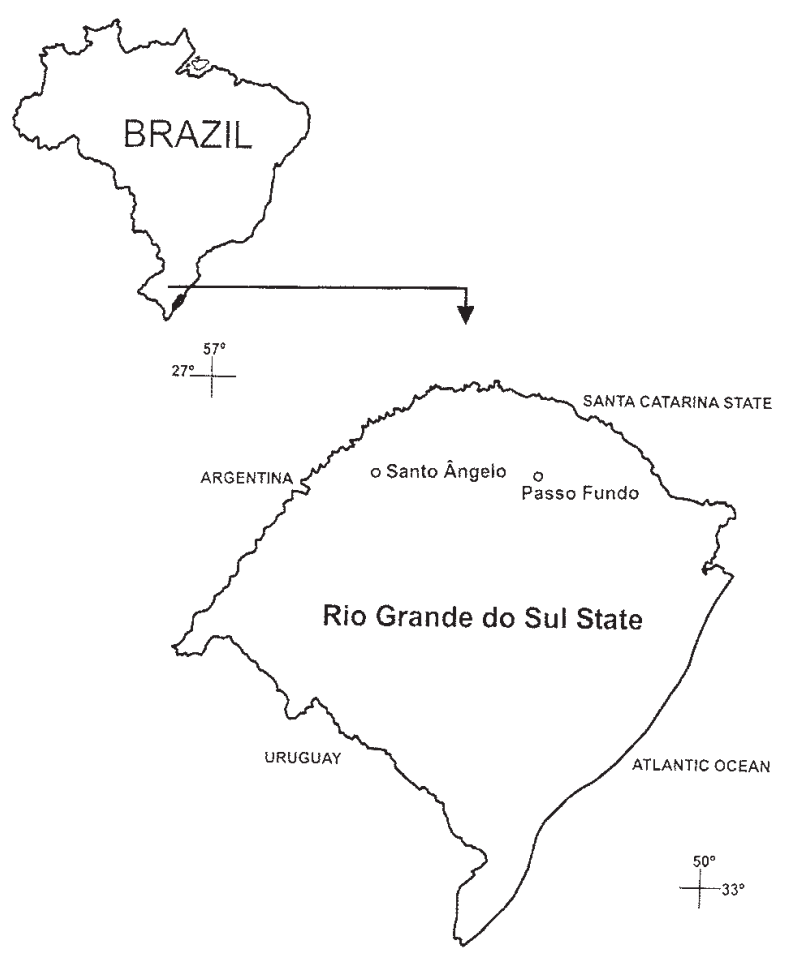

Figure 1 - Location of sampling sites. elevations between 200 and $400 \mathrm{~m}$ above sea level (a.s.1.). The climate is Cfa in the Köppen system, with mean annual temperature of $19.5^{\circ} \mathrm{C}$ and mean precipitation of 1,850 $\mathrm{mm} \mathrm{yr}^{-1}$ (BRASIL, 1973). Samples from conventional (CT) and no-tillage (NT) systems treatments were collected in Santo Ângelo, Rio Grande do Sul State ( $28^{\circ} 16^{\prime} \mathrm{S}, 54^{\circ} 13^{\prime} \mathrm{W}$, approx. $280 \mathrm{~m}$ a.s.1.). The tillage experiment was established in 1979 in a field that had been under a wheat-soybean rotation since 1964 (Dalla Rosa, 1981). Samples from an undisturbed, forested soil were collected from the nearest protected area of original forest vegetation $\left(28^{\circ} 12^{\prime}\right.$ $\left.\mathrm{S}, 54^{\circ} 13^{\prime} \mathrm{W}\right)$ about 15 kilometers from the experimental site. The soil at the Passo Fundo site was a Typic Haplohumox developed from a mixture of basalt and sandstone and occurs at elevations between 460 and $700 \mathrm{~m}$ a.s.1.. The climate is Cfa1, with mean annual temperature $18^{\circ} \mathrm{C}$ and mean precipitation of $1,750 \mathrm{~mm} \mathrm{yr}^{-1}$. Samples under conventional and notillage systems were collected in Passo Fundo, Rio Grande do Sul State $\left(28^{\circ} 14^{\prime} \mathrm{S}\right.$ and $52^{\circ} 24^{\prime}$ 'W) in an experiment established in 1983 (Kochham \& Denardim, 1997). Soils under native vegetation were sampled in a forested reserve on the experimental station within $0.5 \mathrm{~km}$ of the experimental site.

In each of both sites, three samples of treatment NT and CT were randomly collected in the experimental field, and the three samples from native vegetation $(\mathrm{NV})$ were also randomly collected in forests. Care was taken to keep similar distances among collecting points in the experimental field and in the forests ( 5 to $10 \mathrm{~m}$ ). In this study, NT, CT and NV were refered to as "land uses". Samples from 0 to 5 and from 10 to $15 \mathrm{~cm}$ depth were collected from small pits about 0.3 u 0.3 u $0.20 \mathrm{~m}$ depth and samples from 40 $60 \mathrm{~cm}$ depth were collected using a bucket auger. Airdried samples were gently crushed and passed through a $2 \mathrm{~mm}$ sieve (fine earth fraction). The three field replications of each land use from each site were combined, thoroughly mixed, and then stored in sealed plastic bags. Therefore, lab analyses were performed on one composite sample from each of the three depths, three land uses and two soils, summing up eighteen samples.

Organic carbon was determined by digestion in $\mathrm{K}_{2} \mathrm{Cr}_{2} \mathrm{O}_{7}$ and titration with $\mathrm{Fe}\left(\mathrm{NH}_{4}\right)_{2}\left(\mathrm{SO}_{4}\right)_{2} 6 \mathrm{H}_{2} \mathrm{O}$ and particle size distribution was determined by the pipette method after dispersion with $6 \% \mathrm{NaOH}$ (EMBRAPA, 1997). Both analyses were performed twice for each composite sample.

Both WDC and aggregate stability of the composite samples were made three times (three runs) by the standard method for WDC determination (USDA, 1996). Shortly, five $10 \mathrm{~g}$ aliquots of fine earth were 
weighed and placed into $250 \mathrm{~mL}$ plastic bottles. The bottles were filled with $175 \mathrm{~mL}$ of deionized (DI) water and shaken (120 excursions per minute, $4 \mathrm{~cm}$ horizontal displacement) for $0,3.75,7.5,15$ and 27 hours (one aliquot for each time period). The suspensions were then poured through a nest of five sieves of 1000 Pm, 500 Pm, 250 Pm, 106 Pm and 53 Pm. Disaggregated clay and silt were gently washed from the soil on the sieves with DI water and collected in $1 \mathrm{~L}$ cylinders for WDC determination. The soil material retained on the sieves was dried at $110^{\circ}$ for 24 hours and weighed. Soil material that passed through the nest of sieves was collected in one liter cylinders and re-suspended for WDC measurement by the pipet method (USDA, 1996). Slacking was assumed to be negligible, since samples submitted only to rapid wetting were almost entirely aggregated ( $0 \mathrm{~h}$ shaking time on Figures 2 and 3, sum of aggregates).

The mass of aggregates in each size class, $A_{i}$, was calculated by:

$$
\mathrm{A}_{\mathrm{i}}=\left(\mathrm{B}_{\mathrm{i}}-\mathrm{C}_{\mathrm{i}}\right) * 100 / \mathrm{D},
$$

where $B_{i}$ is the dry mass of soil material in size class $\mathrm{i}, \mathrm{C}_{\mathrm{i}}$ is the dry mass of sand in size class $\mathrm{i}$ and $\mathrm{D}$ is the initial oven-dry mass of soil. $\mathrm{C}_{\mathrm{i}}$ was the average of three previous determinations of sand content in each composite sample. Sand was subtracted from the numerator of equation [1] to avoid counting individual sand grains as aggregates. For brevity, we use the term "aggregates" to refer to $\mathrm{Ai}$, , and "sample" for the composite sample, in the discussion that follows.

The distribution of aggregates was analyzed as a split plot design with three treatments (NT, CT, NV) with three blocks (each one of the three runs) replicated over time. Data for each soil type, depth and size class were analyzed separately. Shaking time was considered the whole unit and land use the sub unit of the split plot experiment. For the percent soil mass data, a square root transformation was performed prior to analysis of variance in order to achieve homogeneity of error variance. Error (a) was pooled with error (b) because it was not significant $(P=$ 0.25 ) in the majority of cases. Time and land use versus time effects were partitioned into orthogonal polynomial contrasts. Regressions on the means of the dependent variables as a function of land use and time was followed by the analysis of variance (ANOVA) with the regression model determined by the significant treatment effects and contrasts. Comparison among regressions models of disaggregation from each land use (along shaking times) through ANOVA is shown in Table 2.

\section{RESULTS AND DISCUSSION}

Because sand content was subtracted from the mass of soil material retained in each size class (equation [1]), the sandier Typic Haplohumox (Table 1) had fewer soil aggregates in each size class than the Typic Haplorthox.

Prior to shaking ( $0 \mathrm{~h}$ shaking time; Figures 2 and 3), from 73 to $91 \%$ of the Typic Haplorthox and from 54 to $69 \%$ of the Typic Haplohumox occurred in aggregates. With only two exceptions, regressed disaggregation models were different $(P=0.01)$ among the three land uses for the $0-5$ and $5-10 \mathrm{~cm}$ sampling depths, but land use had less effect on disagregation models for the 40-60 cm depth (Table 2).

Some common behavior could be observed in both soils (Figures 2 and 3): there were very few 106-

Table 1 - Basic sample characterization of the Typic Haplorthox and Typic Haplohumox soils (average 2 replications).

\begin{tabular}{lccccccc}
\hline \multirow{2}{*}{ Soil property } & Depth(cm) & \multicolumn{3}{c}{ Typic Haplorthox } & \multicolumn{3}{c}{ Typic Haplohumox } \\
\cline { 2 - 8 } & & $\mathrm{NT}$ & $\mathrm{CT}$ & $\mathrm{NV}$ & $\mathrm{NT}$ & $\mathrm{CT}$ & $\mathrm{NV}$ \\
\hline Clay $\left(\mathrm{g} \mathrm{kg}^{-1}\right)$ & $0-5$ & 690.0 & 593.0 & 687.6 & 403.0 & 527.0 & 437.0 \\
& $10-15$ & 666.7 & 613.3 & 633.8 & 500.0 & 507.0 & 490.0 \\
& $40-60$ & 753.0 & 767.0 & 693.0 & 630.0 & 640.0 & 590.0 \\
\hline Sand $\left(\mathrm{g} \mathrm{kg}^{-1}\right)$ & $0-5$ & 39.6 & 42.7 & 66.0 & 310.0 & 306.0 & 299.0 \\
& $10-15$ & 38.9 & 41.3 & 63.0 & 305.0 & 286.1 & 299.1 \\
\hline O.C. $\left(\mathrm{g} \mathrm{kg}^{-1}\right)$ & $0-5$ & 28.7 & 27.8 & 56.2 & 224.2 & 203.7 & 207.6 \\
& $10-60$ & 0.33 & 0.28 & 0.57 & 0.31 & 0.24 & 0.34 \\
& $40-60$ & 0.25 & 0.27 & 0.36 & 0.23 & 0.24 & 0.24 \\
\hline
\end{tabular}

O.C. $=$ Organic Carbon; $\mathrm{NT}=$ no-tillage; $\mathrm{CT}=$ conventional tillage; $\mathrm{NV}=$ native vegetation 
Table 2 - Analysis of variance among the regression models for disaggregation curves from the three land uses. $(P$ values).

\begin{tabular}{|c|c|c|c|c|}
\hline \multirow{2}{*}{ Sample } & \multirow{2}{*}{ Size Class (mm) } & \multicolumn{3}{|c|}{ Depth $(\mathrm{cm})$} \\
\hline & & $0-5$ & $10-15$ & $40-60$ \\
\hline \multirow[t]{5}{*}{ Typic Haplorthox } & $2,000-1,000$ & $<0.0000$ & $<0.0000$ & 0.4650 \\
\hline & $1,000-500$ & $<0.0000$ & $<0.0000$ & $<0.0000$ \\
\hline & $500-250$ & 0.4834 & $<0.0000$ & $<0.0000$ \\
\hline & $250-106$ & $<0.0000$ & $<0.0000$ & 0.4650 \\
\hline & $106-53$ & $<0.0000$ & $<0.0000$ & $<0.0000$ \\
\hline \multirow[t]{5}{*}{ Typic Haplohumox } & $2,000-1,000$ & $<0.0000$ & $<0.0000$ & 0.4700 \\
\hline & $1,000-500$ & $<0.0000$ & $<0.0000$ & 0.2208 \\
\hline & $500-250$ & $<0.0000$ & $<0.0000$ & $<0.0000$ \\
\hline & $250-106$ & $<0.0000$ & $<0.0000$ & 0.0130 \\
\hline & $106-53$ & 0.0134 & $<0.0000$ & $<0.0000$ \\
\hline
\end{tabular}

$53 \mathrm{Pm}$ and 250-105 Pm aggregates in soil under native vegetation at $0-5 \mathrm{~cm}$ and $10-15 \mathrm{~cm}$ depths; aggregates larger than $500 \mathrm{Pm}$ in diameter dominated both at $0-5 \mathrm{~cm}$ and $10-15 \mathrm{~cm}$ depths, but at $40-60 \mathrm{~cm}$ depth, aggregates 2,000 - 1,000 Pm in diameter were the least abundant; and although the stacking order of curves in a single graph changed depending on size class and depth, it was noted that curve shapes were, in general, similar for each size class.

There was a small release of WDC upon initial wetting ( $0 \mathrm{~h}$ shaking) in all samples, supporting the assumption that slacking was not a significant disaggregation process under the experimental conditions.

The largest aggregates (2000-1000 Pm and 1000-500 Pm) broke down quickly within the first 7.5 hours of shaking, but the mass of smaller aggregates did not increase concurrently, which showed that such aggregates were mainly broken into primary soil particles and not to small aggregates (Figures 2 and 3). Therefore these soils did not have aggregate hierarchy (Oades \& Waters, 1991). Since WDC increased as aggregates larger than $500 \mathrm{Pm}$ disaggregated, without change in $\mathrm{pH}$ suspensions, disaggregation appears to be the main mechanism of WDC production.

The lack of aggregate hierarchy allows the description of disaggregation by a first order process model (Beare \& Bruce, 1993; Parkin \& Robinson, 1992; Olson, 1963):

$$
\mathbf{A}_{\mathrm{i}, \mathrm{t}}=\mathbf{A}_{\mathrm{i}, 0} * \mathrm{e}^{-\mathrm{kt}}
$$

where $\mathbf{A}_{\mathbf{i}, \mathbf{t}}$ is the mass of aggregates in size class $\mathrm{i}$ at time t, $\mathbf{A}_{i, 0}$ is the mass of aggregates at time 0 , and $\mathbf{k}$ is a curvature parameter. This model does not account for additions of aggregates to sieve i, produced by the disaggregation of aggregates in the sieve $i+1$ above it, and so can only be used in soils with no aggregate hi- erarchy. The curvature parameter $(\mathrm{k})$ was assumed as disaggregation rate index, and the greater its absolute value, the smaller the aggregate stability. No recognizable pattern was found when organizing the $\mathrm{k}$ values according to land use. However, when the range of variantion of $\mathrm{k}$ was plotted according to aggregate size class, a reasonably clear trend appeared (Figures 4 and $5)$, indicating that $\mathrm{k}$ values were clustered around successively larger values as size class increases. This suggests that land use had more impact on the amount of soil material in each size class (aggregate distribution, Figures 2 and 3 ) than on aggregate stability.

The effect of land use on the $\mathrm{k}$ values can be inferred from the dispersion of values at each depth and size class (points along each line on Figures 4 and 5). Although not dominant, the effect of land use is greatest (larger range) in size classes larger than $500 \mathrm{Pm}$ and in surface horizons (Figures 4 and $5)$. This is in agreement with the aggregation model suggested by Oades \& Waters (1991), in which large aggregates are more dependent of fungal hyphae and fine roots, and therefore on land use, while the small aggregates depends more on soil colloidal properties and chemistry.

Considering that the release of WDC was closely related to the disaggregation of aggregates larger than $500 \mathrm{Pm}$, that the conventional and no-tillage systems promoted a decrease in the amount of large aggregates, and that there is no aggregate hierarchy, a considerable amount of clay can potentially be lost during the change from forest to agricultural land use. In all cases, maintenance of large aggregates is, according to these results, essential to avoid an increase in WDC. Adding to this, complexes of clay minerals and organic colloids, which increase the potencial for dispersion, should be greater in the surface horizons (Tombácz et al., 2004). 

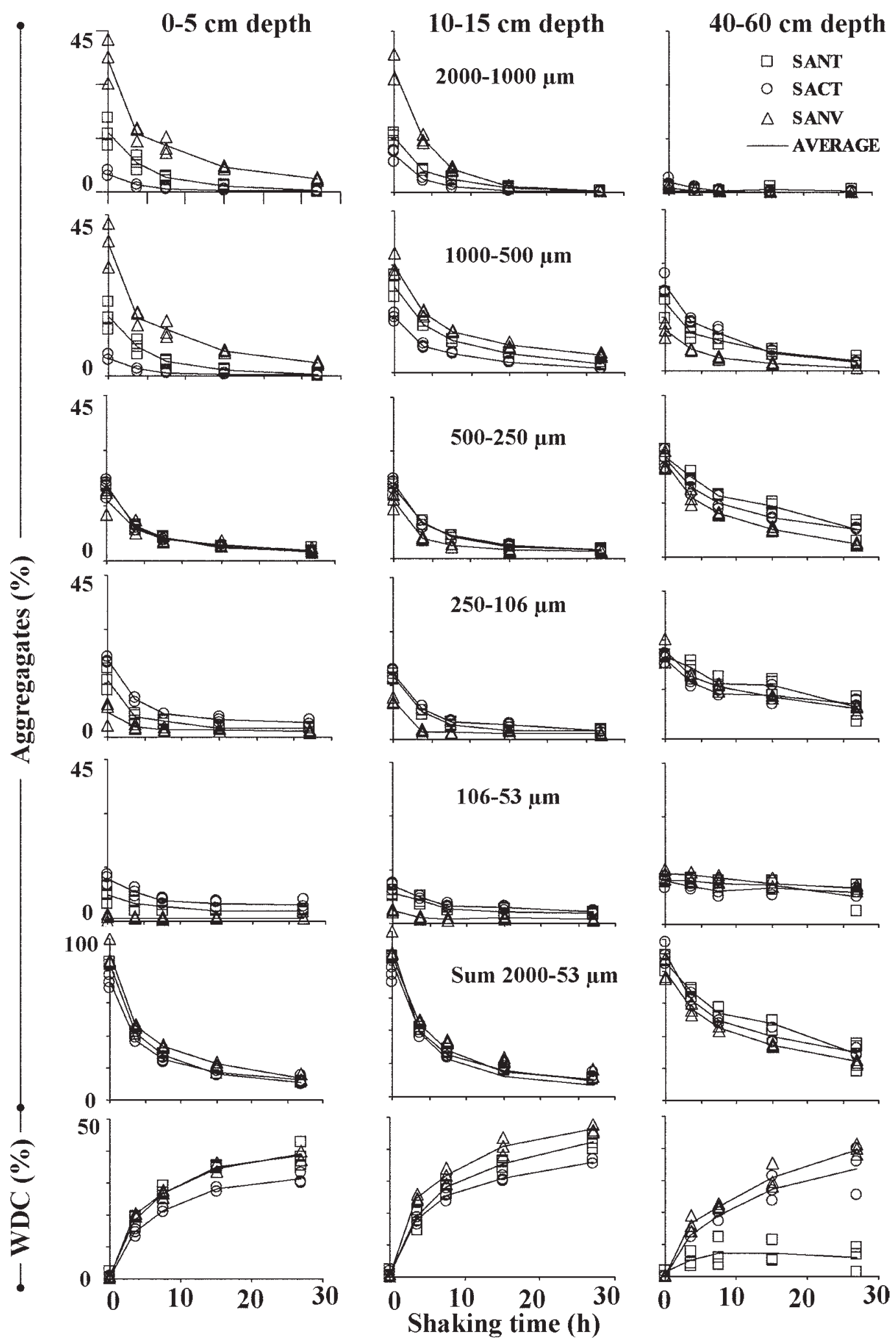

Figure 2 - Disagreggation curves and water dispersible clay (WDC) for the Typic Haplorthox, for depths 0-5; 10-15; 40-60 cm. Sci. Agric. (Piracicaba, Braz.), v.64, n.1, p.36-43, January/February 2007 


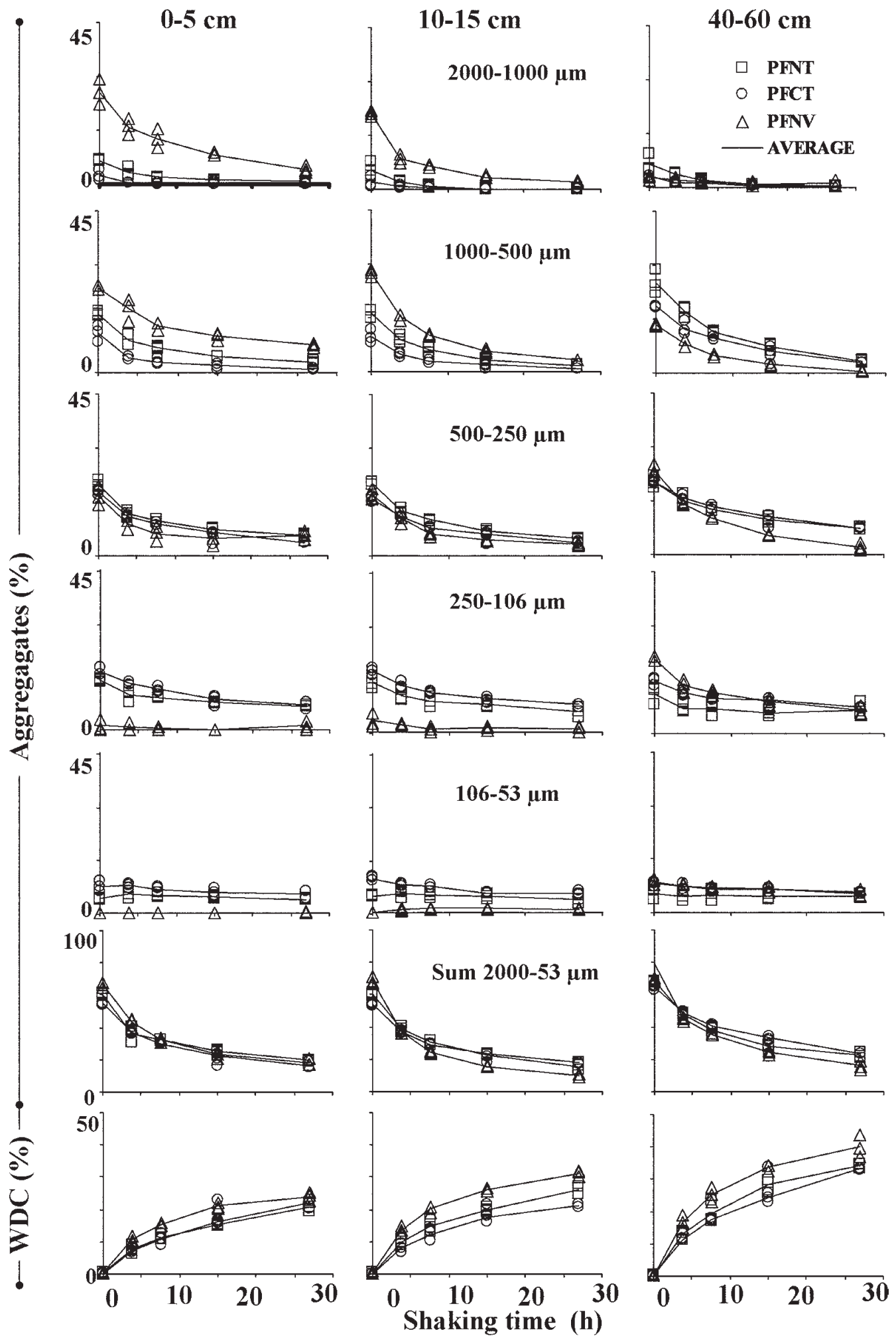

Figure 3 - Disagreggation curves and water dispersible clay (WDC) for the Typic Haplohumox, for depths 0-5; 10-15; 40-60 cm. 

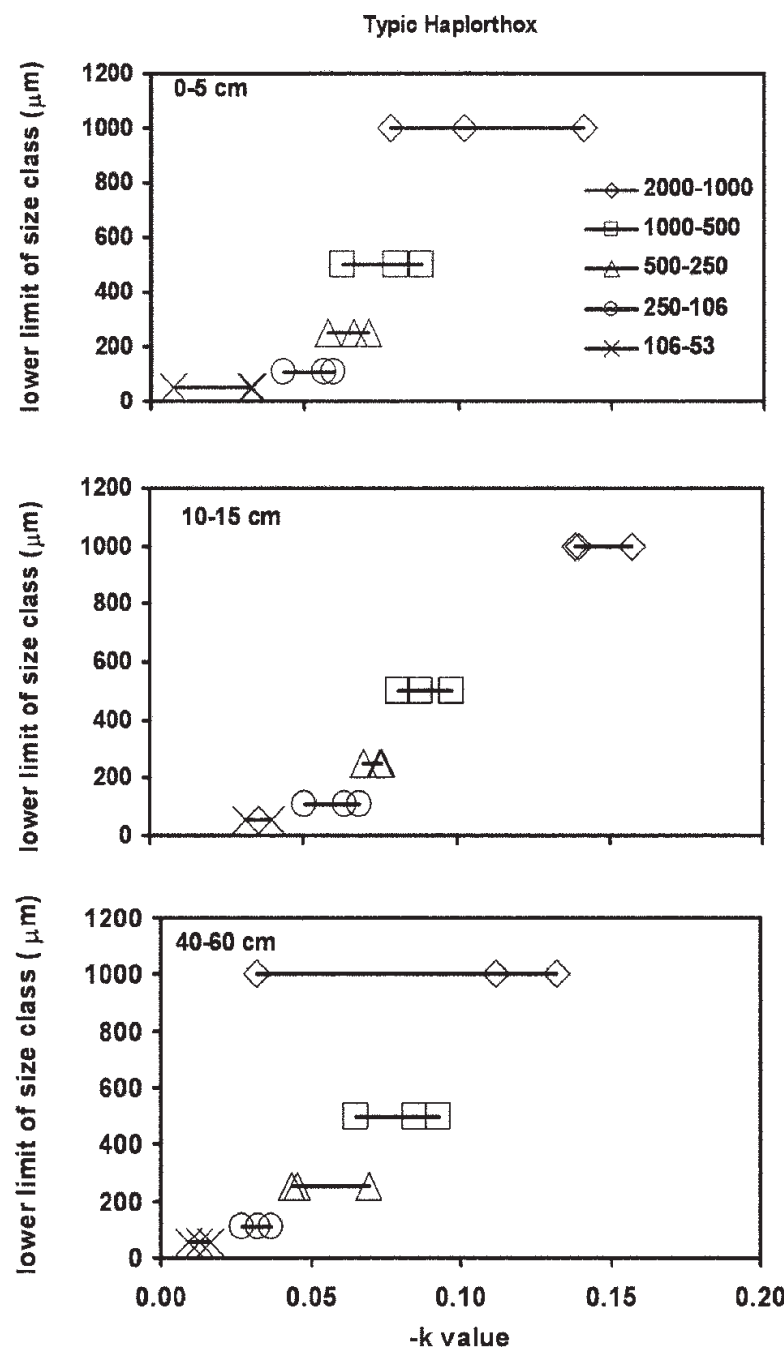

Figure 4 - Parameter $\mathrm{k}$ for the five aggregate size classes (all three land uses) in the Typic Haplorthox soil arranged by depth (top: $0-5 \mathrm{~cm}$ depth; middle: $10-15 \mathrm{~cm}$ depth; bottom: $40-60 \mathrm{~cm}$ depth).

\section{ACKNOWLEDGEMENTS}

To CAPES-Brazil (BEX 1316-96/6), Purdue Agricultural Research Programs journal article number 2006-17943, and To A. Dallarosa and J. Becker, from COTRISA; J. E. Denardin and R. A. Kochham, from EMBRAPA.

\section{REFERENCES}

AZEVEDO, A.C.; BONUMÁ, A.S. Partículas coloidais, dispersão e agregação em Latossolos. Ciência Rural, v.34, p.609-617, 2004.

BEARE, M.H.; BRUCE, R.R. A comparison of methods for measuring water-stable aggregates: implications for determining environmental effects on soil structure. Geoderma, v.56, p.87-104, 1993.

BERTSCH, P.M.; SEAMAN, J.C. Characterization of complex mineral assemblages: implications for contaminant transport and environmental remediation. Proceedings of National Academy of Science USA, v.96, p.3350-3357, 1999.
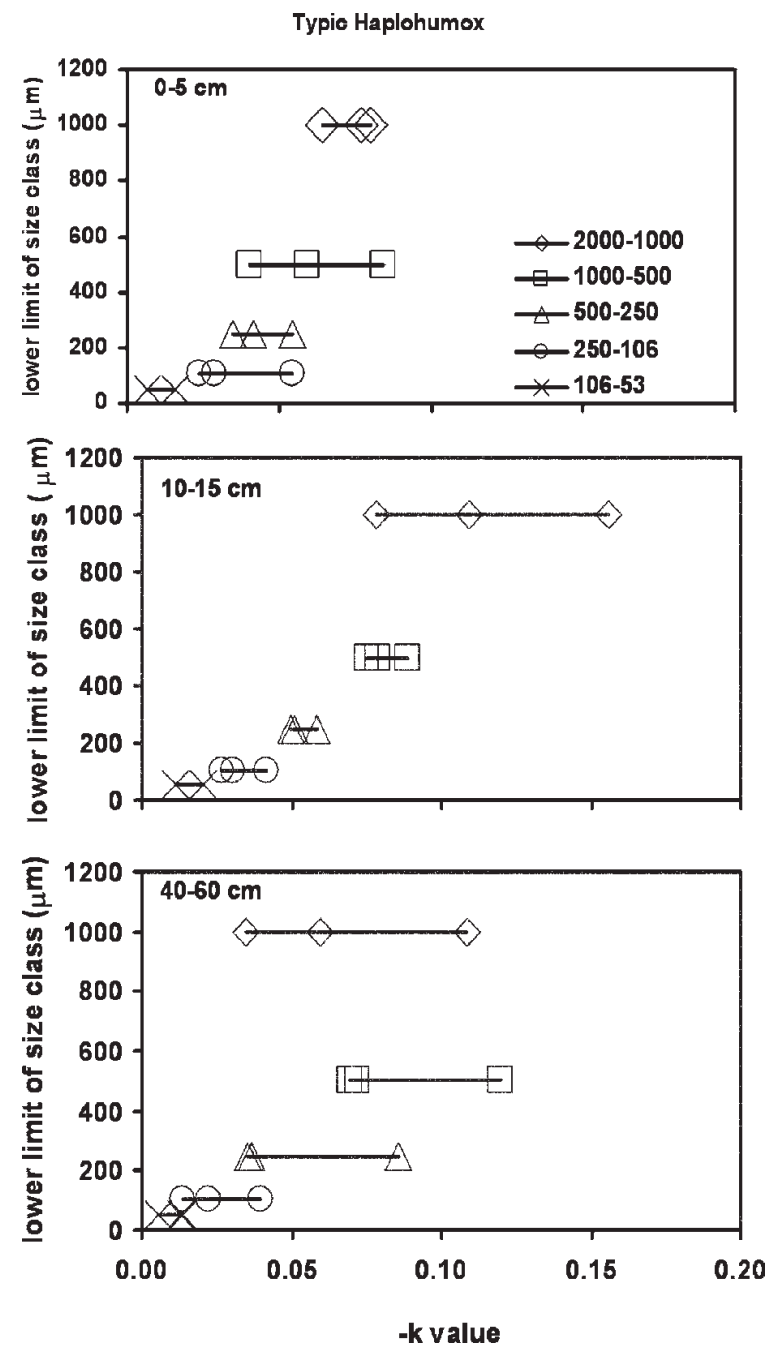

Figure 5 - Parameter $\mathrm{k}$ for the five aggregate size classes (all three land uses) in the Typic Haplohumox soil arranged by depth (top: 0-5 cm depth; middle: 5-10 cm depth; bottom: 40-60 cm depth).

BOIX-FAYOS, C.; CALVO-CASES, A.; IMESON, A.C.; SORIANOSOTO, M. D. Influence of soil propetties on the aggregation of some Mediterranean soils and the use of aggregate size and stability as land degradation indicators. Catena, v.4, p.47-67, 2001.

BRASIL. Levantamento de reconhecimento dos solos do Estado do Rio Grande do Sul. Brasília: Ministério da Agricultura, SNLCS, 1973. 431p.

BUOL, S.W.; ESWARAN, H. Oxisols. Advances in Agronomy, v.68, p.151-195, 2000

CARAVACA, F.; LAX, A.; ALBALADEJO, J. Aggregate stability and carbon characteristics of particle-size fractions in cultivated and forested soils of semiarid Spain. Soil and Tillage Research. v.78, p.83-90, 2004.

CARPENEDO, V.; MIELNICZUK, J. Estado de agregação e qualidade de agregados de Latossolos Roxos, submetidos a diferentes sistemas de manejo. Revista Brasileira de Ciência do Solo, v.14, p.99-105, 1990.

DALLA ROSA, A. Práticas mecânicas e culturais na recuperação de características físicas de solos degradados pelo cultivo - solo Santo Ângelo (Latossolo Roxo distrófico). Porto Alegre: UFRGS/Faculdade de Agronomia, 1981. 136p. (Dissertation M. S.). 
EMBRAPA. Manual de métodos de análise de solos. 2nd. Rio de Janeiro: EMBRAPA, 1997. 212pp.

KOCHHAM, R.A.; DENARDIM, J.E. Comportamento das culturas de trigo, soja e milho à adubação fosfatada nos sistemas plantio direto e preparo convencional. In: CONGRESSO BRASILIERO DE CIÊNCIA DO SOLO, 26., Rio de Janeiro, 1997. SBCS, 1997.

LEITE, L.F.C.; MENDONÇA, E.S.; MACHADO, P.L.O.A.; FERNANDES FILHO, I.E.;NEVES, J.C.L.. Simulating trends in soil organic carbon of an Acrisol under no-tillage and disc-plow systems using the Century model. Geoderma, v.12, p.283-295, 2004.

OADES, J..M.; WATERS, A.G. Aggregate hierarchy in soils. Australian Journal of Soil Research, v.29, p.815-828, 1991.

OLSON, J.S. Energy storage and the balance of producers and decomposers in ecological systems. Ecology, v.44, p.322-331, 1963.

PARKIN, T.B.; ROBINSON, J.A. Analysis of log normal data. Advances in Soil Science, v.20, p.193-235, 1992.

PERIN, E.; CERETTA, C.A.; KLAMT, E. Tempo de uso agrícola e propriedades químicas de dois Latossolos do Planalto Médio do Rio Grande do Sul. Revista Brasileira de Ciencia do Solo, v.27, p.665674, 2003.
SETA, A.K.; KARATHANASIS, A.D. Water dispersible colloids and factors influencing their dispersibility from soil aggregates. Geoderma, v. 74, p.255-266, 1996.

TOMBACZ, E.; LIBOR, Z.; ILLES, E.; MAJZIK, A.; KLUMPP, E.. The role of reactive surface sites and complexation by humic acids in the interaction of clay mineral and iron oxide particles. Organic Geochemistry. v.35, p.257-267, 2004.

TORN, M.S.; TRUMBORE, S.E.; CHADWICK, O.A.; VITOUSEK, P.M.; HENDRICKS, D..M. Mineral control of soil organic carbon storage and turnover. Nature, v.389, p.170-173, 1997.

USDA. Soil survey laboratory methods manual. 3.0. Washington: NRCS, NSSC. 1996. 693p.

YANAI, R.D.; CURRIE, W.S.; GOODALE, C.L. Soil Carbon Dynamics after Forest Harvest: An Ecosystem Paradigm Reconsidered. Ecosystems, v.6, p.197-212, 2003.

ZINN, Y.; LAL, R.; RESCK, D.V.S. Texture and organic carbon relations described by a profile pedotrasnfer function for Brazilian Cerrado soils. Geoderma, v.127, p.168-173, 2005.

Received March 16, 2006

Accepted November 09, 2006 